\title{
Essential trace elements in meat, spleen and liver of Brahman Cross steers reared in intensive production system in Bandung, Indonesia
}

\author{
D.D. Lestiani ${ }^{1}{ }^{1 *}$, M. Santoso ${ }^{1}$, E.Y. Setyowati ${ }^{2}$, S. Kurniawati ${ }^{1}$, N. Adventini ${ }^{1}$ and E. Damastuti $^{1}$ \\ ${ }^{1}$ Center for Applied Nuclear Science and Technology, \\ National Nuclear Energy Agency of Indonesia, \\ Jl. Tamansari no. 71 Bandung 40132 - Indonesia \\ ${ }^{2}$ Faculty of Animal Husbandry, Padjajaran University, \\ Jl. Raya Bandung-Sumedang Km 21, Jatinangor Bandung 45363 - Indonesia \\ *Corresponding E-mail: diahdwi@batan.go.id
}

Received February 23, 2018; Accepted July 16, 2018

\begin{abstract}
ABSTRAK
Pada penelitian ini dilakukan penentuan unsur mineral mikro (selenium, besi dan seng) pada daging, limpa dan hati sapi. Sapi jantan kebiri Brahman Cross dipelihara pada sistem produksi intensif untuk penggemukan selama 87 hari. Sampel daging, limpa dan hati dari 16 ekor sapi jantan kebiri berumur 24-36 bulan, dengan empat perlakuan pemberian pakan tanpa selenium (kelompok I) dan penambahan selenium organik 0,3 ppm masing-masing selama 25, 50 dan 75 hari (kelompok II, III dan IV). Sampel dianalisis menggunakan analisis aktivasi neutron instrumental (AANI) menggunakan fasilitas iradiasi reaktor G.A Siwabessy. Hasil analisis menunjukkan adanya peningkatan kandungan Se pada daging dan hati setelah pemberian suplementasi selama 75 hari. Konsentrasi rerata Se pada daging untuk kelompok I, II, III dan IV masing-masing sebesar 0,13;0,17;0,20 dan 0,31 mg/kg berat basah, sedangkan untuk hati masing-masing 0,$43 ; 0,53 ; 0,60$ dan $0,70 \mathrm{mg} / \mathrm{kg}$. Konsentrasi rerata untuk besi dalam daging, limpa dan hati masing-masing sebesar 11,85; 139 dan 38,94 mg/kg, dan untuk seng sebesar 27,90; 21,70 dan 25,27 mg/kg. Pada studi ini, limpa dan hati memberikan kontribusi lebih dari $100 \%$ terhadap angka kecukupan gizi (AKG) Se bagi anak-anak dan orang dewasa. Limpa memiliki kontribusi AKG Fe 53-154\%, sedangkan AKG Zn dikontribusikan dari daging sapi sebesar 21-56\%.
\end{abstract}

Kata kunci : mineral penting, unsur trace, analisis aktivasi neutron, angka kecukupam gizi

\begin{abstract}
In this study the determination of micro mineral elements (selenium, iron and zinc) in meat, spleen and liver of beef were carried out. Brahman cross steers reared under intensive production system in feedlot for 87 days. Samples of meat, spleen and liver were collected from 16 steers aged 24-36 months with four types of feeding treatment, feeding without Se (group I) and feeding with additional supplementary of $0.3 \mathrm{ppm}$ selenium for 25,50 and 75 days (group II, III and IV, respectively). Samples characterization were carried out by instrumental neutron activation analysis (INAA) using irradiation facility in G.A Siwabessy Serpong reactor. Analysis results showed that there is an increasing of selenium content in meat and liver after 75 days feeding. The mean of selenium in liver for group I, II, III and IV were $0.13,0.17,0.20$ and $0.31 \mathrm{mg} / \mathrm{kg}$ wet weight, respectively, while for liver were 0.43 , $0.53,0.60$ and $0.70 \mathrm{mg} / \mathrm{kg}$ wet weight, respectively. The mean concentrations for iron in meat, spleen and liver were $11.85,139$, and $38.94 \mathrm{mg} / \mathrm{kg}$, respectively, for zinc were $27.90,21.70$ and $25.27 \mathrm{mg} / \mathrm{kg}$,
\end{abstract}


respectively. In this study, the meat and liver contribute more than $100 \%$ of recommended daily allowance (RDA) of Se for children and adults. Spleen have contribution of RDA of Fe 53 to 154\%, while the RDA of $\mathrm{Zn}$ is contributed mostly from meat by 21 to $56 \%$.

Keywords:essential, trace elements, neutron activation analysis, recommended daily allowance

\section{INTRODUCTION}

In Indonesia, dietary intakes of some essential trace elements i.e. iron and zinc tend to be low, as well as the increasing concern related selenium deficiency, especially among infant and women living in rural areas, the deficiency of iron, zinc and selenium are still prevalent in Indonesia (Tidemann-Andersen et al., 2011; Diana et al., 2017; Fahmida et al., 2014; Ministry of Health Republic Indonesia, 2016). Mineral especially micro elements have an important role in the various processes of the body especially in physiological and metabolism (Bailey et al., 2015; Elmadfa and Meyer, 2008). Selenium (Se) acts an important role as an antioxidant enzyme which has function to protect cells against the impact of free radicals, enzymes cofactor in fatty acid oxidation and can be used to prevent premature aging as well as to prevent heart-related diseases and several types of cancers, while iron ( $\mathrm{Fe}$ ) plays an important role in the process of red blood cells formation, and reduces the risk of anemia; zinc (Zn) works in maintaining immune system function, and growth (Saini et al., 2016; Mutakin et al., 2016; Abbaspour et al., 2014; King et al., 2016; Lynch et al., 2016).

Meat is one of the foods rich in protein and other essential micro minerals such as selenium, iron, zinc and other vitamins when compared to other foods (Pilarczyk, 2014). In Indonesia, the numbers of beef and veal consumption in 2017 compared with 2016, only increased slightly 6 percent from 1.8 to $1.9 \mathrm{~kg}$ per capita (OECD/FAO, 2017). When compared with some neighboring countries, Indonesia is still very far behind. Malaysia's per capita consumption of beef and veal is $5.4 \mathrm{~kg}$ per year, while the Philippines reaches $2.9 \mathrm{~kg}$ per year, and Uruguay is much higher with $43.1 \mathrm{~kg}$ per capita per year (OECD/FAO, 2017).

Determination of essential trace element concentrations in beef is important for assessing the micronutrient intake from animal contributing to human nutrition. The concentration of essential trace elements in meat differs which is influenced by several things such as breed, sex, age, and the production system (feeding practices and geographical conditions) (Gerber et al., 2009; Pereira et al., 2017; Czerwonka and Szterk, 2015). Study on essential trace elements such as $\mathrm{Se}, \mathrm{Fe}$ and $\mathrm{Zn}$ in beef have been conducted by other researchers for meat from US (Gerber et al., 2009), Australia, Denmark, and UK (Williamson et al., 2005) and New Zealand (Purchas et al., 2014). Most of the research studied the various type of meat (rib eye, sirloin, tenderloin), but not spleen and liver since these organ were not commonly consumed in those study areas. In Indonesia, reported data for essential trace elements in beef from Indonesia were still limited, not only for meat, but spleen and liver are also scarce. Setyowati has been reported the results on selenium on meat, but other organ (liver and spleen) and other elements such as Fe and $\mathrm{Zn}$ were not discussed yet (Setyowati, 2010). Previous study related to iron content in meat and micronutrients in meat, spleen and liver have been published elsewhere (Natalia et al., 2010; Natalia et al., 2011), but it has a limitation in samples diversity, statistical analysis and the impact of selenium supplementation, therefore, a more comprehensive study needs to be conducted to get representative results.

The content of trace elements have studied mostly in beef from animal kept in industrial areas or fed on natural pasture (Pilarczyk, 2014). Blanco-Penedo studied has showed that the type of farm production (organic, intensive or conventional system) may vary significantly the accumulation of essential trace elements in cattle between farms (Blanco-Penedo et al., 2010). However, most of the meat consumed in Indonesia were taken from animals fed intensively in local farms or imported from Australia (Blanco-Penedo et al., 2010). Research on beef fed in intensive production system is more significant for customer (Pilarczyk, 2014). Therefore, in this study sixteen samples of meat, spleen and liver from Brahman cross steers reared in intensive production system in Bandung were collected and analyzed using instrumental neutron activation analysis (INAA). INAA is one of nuclear analytical techniques that widely used in characterization of trace elements in several matrices of samples, it is highly sensitive, non- 
destructive, multi-elemental, accurate, and precise, and has a good limit detection (Syahfitri et al., 2017; Moon et al., 2015).

\section{MATERIALS AND METHODS}

\section{Animals}

Sixteen Brahman cross steers were reared under intensive production systems, fattened to approximately $380-420 \mathrm{~kg}$ body weight at age $24-$ 36 month. They were maintained indoors on a teaching farm at Padjadjaran university located in Bandung, the capital city of West Java. They were grouped into four treatments that were fed with organic selenium $0.3 \mathrm{ppm}$ within the complete concentrate. Each groups consists of 4 steers, the first group were fed with no selenium concentrate, the II, III and IV groups were fed with $0.3 \mathrm{ppm}$ of organic selenium supplement in the last 25,50 and 75 days of 87 days fattening period, respectively (Setyowati, 2010). The concentrate were produced on the farm which consists of rice husk powder, soy sauce waste, copra meal, cassava chips, polard, and ultra mineral (Setyowati, 2010).

\section{Sample Collection and Preparation}

All animals were slaughtered in an authorized slaughterhouse. Samples of meat, liver and kidney were collected 18 hours after chilling process at $10^{\circ} \mathrm{C}$ and packed in the plastic bag (Setyowati, 2010). Meat, spleen and liver was weighed about 25-50 g, then mashed and homogenized using titanium blade-blender. The mashed samples then weighed and frozen in a freezer with $-20^{\circ} \mathrm{C}$. The frozen samples then dried using freeze dryer at a temperature of $-55^{\circ} \mathrm{C}$ under vacuum for 48-72 hours. Dried samples were crushed into the fine powder using mortar agate, and placed into plastic bottle. Preparation for NAA was carried out by weighing 25-50 mg of dried samples and put into $0.3 \mathrm{~mL}$ plastic vial then sealed by heating (Syahfitri et al., 2017). The standard for NAA was also prepared using ICP multi-element standard (E Merck), then dropped by pipetting $100 \mathrm{~mL}$ of standard into the vial. The amount of standard for each elements $\mathrm{Se}, \mathrm{Fe}$ and $\mathrm{Zn}$ were $0.1,40$ and $1.0 \mu \mathrm{g}$, respectively. The mixed standard contained vial was dried in the infrared lamp then sealed by heating (Syahfitri et al., 2017).

\section{Sample Analysis}

Meat, spleen and liver samples, reference material (RM) NIST 8414 Bovine Muscle Powder and ICP multi-element standard were irradiated for 120 minutes using rabbit irradiation facility with thermal neutron flux of $10^{13} \mathrm{n} \cdot \mathrm{cm}^{-2} \cdot \mathrm{s}^{-1}$ in research reactor G.A. Siwabessy, Serpong. After appropriate cooling (30-40 days), samples were counted for \pm 60000 seconds using HPGe gamma spectrometer with an efficiency of $35 \%$ and FWHM of $2.0 \mathrm{keV}$ at $1.33 \mathrm{MeV}$ from a Co-60 source. The spectrum was analysed using Genie 2000 software. Using comparative method, net areas from each peak were used to calculate the concentrations of elements in the samples (Atmodjo et al., 2017). The similar matrix of standard reference material (SRM) was used in quality control assessment to ensure the validity of the analytical results. The SRM value obtained from the measurement were compared with the certificate value, and then evaluated their accuracy and precision for each element by \%recovery and \%relative standard deviation (RSD) calculation. $\mathrm{Se}, \mathrm{Fe}$ and $\mathrm{Zn}$ were determined in each specific energy. The photopeak of ${ }^{75} \mathrm{Se}$ at $279.5 \mathrm{keV}$ interferes with the full energy peak of ${ }^{203} \mathrm{Hg}$. This overlapping problem was resolved by calculating the selenium from other non-interfering peak of selenium in $264.7 \mathrm{keV}$. Iron was detected with good precision and no interferences using $1099 \mathrm{keV}$ photopeak, while zinc is determined using the $1115.5 \mathrm{keV}$ gamma ray of ${ }^{65} \mathrm{Zn}$ (IAEA International Atomic Energy Agency, 1992).

\section{Statistical data analysis}

Statistical data analysis was performed using software. The significant differences was tested by one-way ANOVA and Duncan's test. In all cases, statistical significance was indicated by $\mathrm{P}<0.05$.

\section{RESULTS AND DISCUSSIONS}

The quality assurance, accuracy and precision of analysis results using NAA was checked by applying the same experimental procedure to the certified reference materials namely NIST-RM 8414 Bovine muscle powder. In general, there was good suitability between the measured and certified values (Table 1). Overall, the average concentrations per wet weight for selenium in meat, spleen and liver were 0.20, 0.33 , and $0.57 \mathrm{mg} / \mathrm{kg}$, respectively. Average concentration of iron in meat, spleen and liver 
were $11.85,139$, and $38.94 \mathrm{mg} / \mathrm{kg}$, respectively, and for zinc were $27.90,21.70$, and $25.27 \mathrm{mg} / \mathrm{kg}$, respectively. The concentration of iron and zinc in meat, spleen and liver is shown in Figure 1, while selenium is shown in Figure 2.

\section{Selenium Supplementation}

The results obtained for $\mathrm{Se}, \mathrm{Fe}$ and $\mathrm{Zn}$ trace elements concentrations in meat, spleen and liver based on the treatment of organic selenium supplementation of group I, II, III and IV were resumed in Table 2. For selenium supplementation impact, based on one way ANOVA and Duncan test, there were statistically significant differences for selenium concentrations in meat between the group I and group II to group IV (Table 3). Group II (25 days) and III (50 days) has no significant differences with the control. It means that selenium in meat were significantly increased after 75 days of supplementation (Setyowati, 2010). These results were similar with the research results obtained by Vignola et al. (2009) which they concluded that the content of Se meat increases with the higher level of organic Se giving in its rations. They reported the content of $\mathrm{Se}$ in meat control and treatment with supplementation of $0.3 \mathrm{mg} / \mathrm{kg}$ Se-yeast were 0.35 $\mathrm{mg} / \mathrm{kg}$ and $0.66 \mathrm{mg} / \mathrm{kg}$, respectively (Vignola et al., 2009). The difference of Se content is in accordance with Hintze et al. (2002) which states that the concentration of Se in meat is affected by the level of Se in the rations (Hintze et al., 2002). Selenium in liver was also showed statistically significant differences between control group and others groups. The Se concentration in liver was raised after 25 days of supplementation feeding. It showed that the increase in liver was higher than in meat. Other studies found that the $\mathrm{Se}$ concentration in liver increased higher that of other organs (brains, hair, heart, kidney, pancreas, tendon and testicles) (Seboussi et al., 2010; Ekholm et al., 1991). The increased selenium in supplemented groups was more seen in kidney and liver followed by spleen and diaphragm (Ekholm et al., 1991; Seboussi et al., 2010). Depending on the type of different tissues, the

Table 1. Quality Control Assessment using NIST RM 8414 Bovine Muscle Powder

\begin{tabular}{cccccr}
\hline Elements & Certificate Value $(\mathrm{mg} / \mathrm{kg})$ & AnalysisrResults $(\mathrm{mg} / \mathrm{kg})$ & \% Recovery & \%RSD \\
\hline $\mathrm{Se}$ & $0.076 \pm 0.010$ & $0.0761 \pm 0.029$ & 100.1 & 6.8 \\
$\mathrm{Fe}$ & $71.2 \quad \pm 9.2$ & 73.4 & \pm 5.7 & 103.1 & 15.3 \\
$\mathrm{Zn}$ & $142 \quad \pm 14$ & 144 & \pm 2 & 101.7 & 5.6 \\
\hline
\end{tabular}

RSD (relative standard deviation)

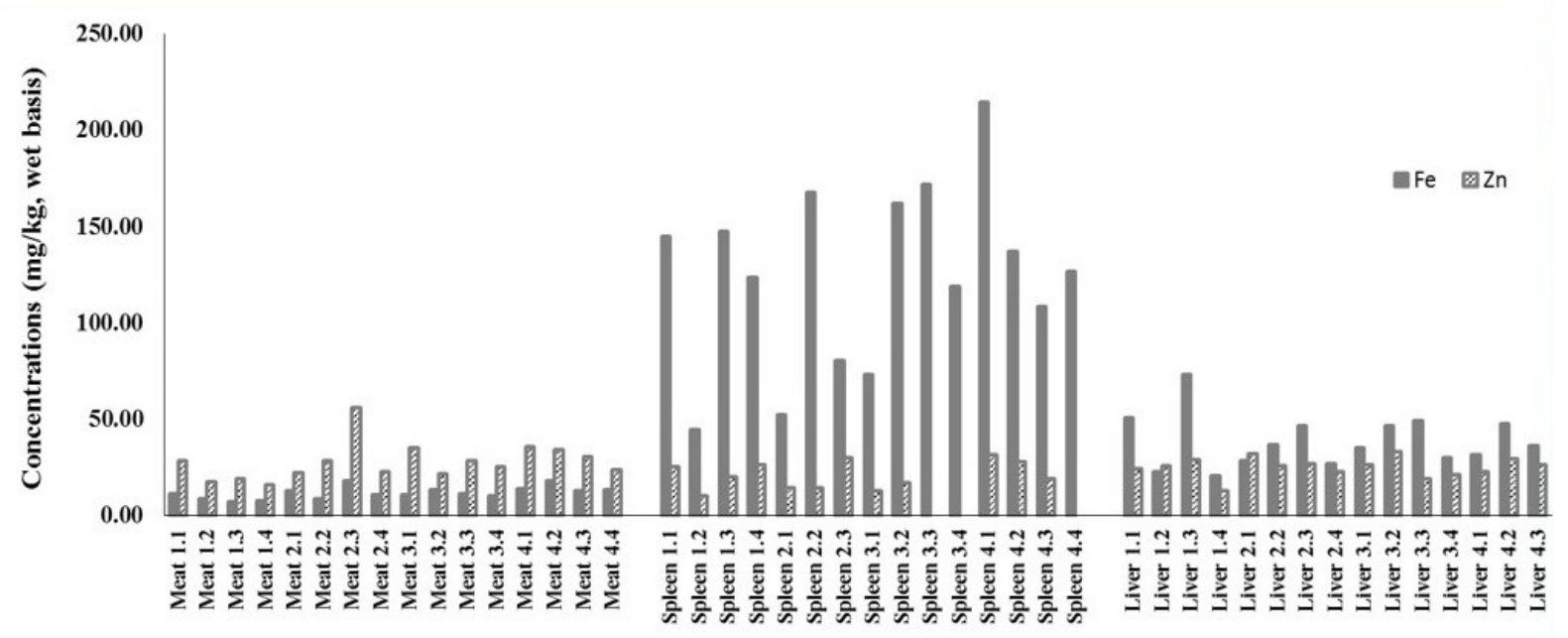

Figure 1. Iron and Zinc Concentrations in Meat, Spleen and Liver 


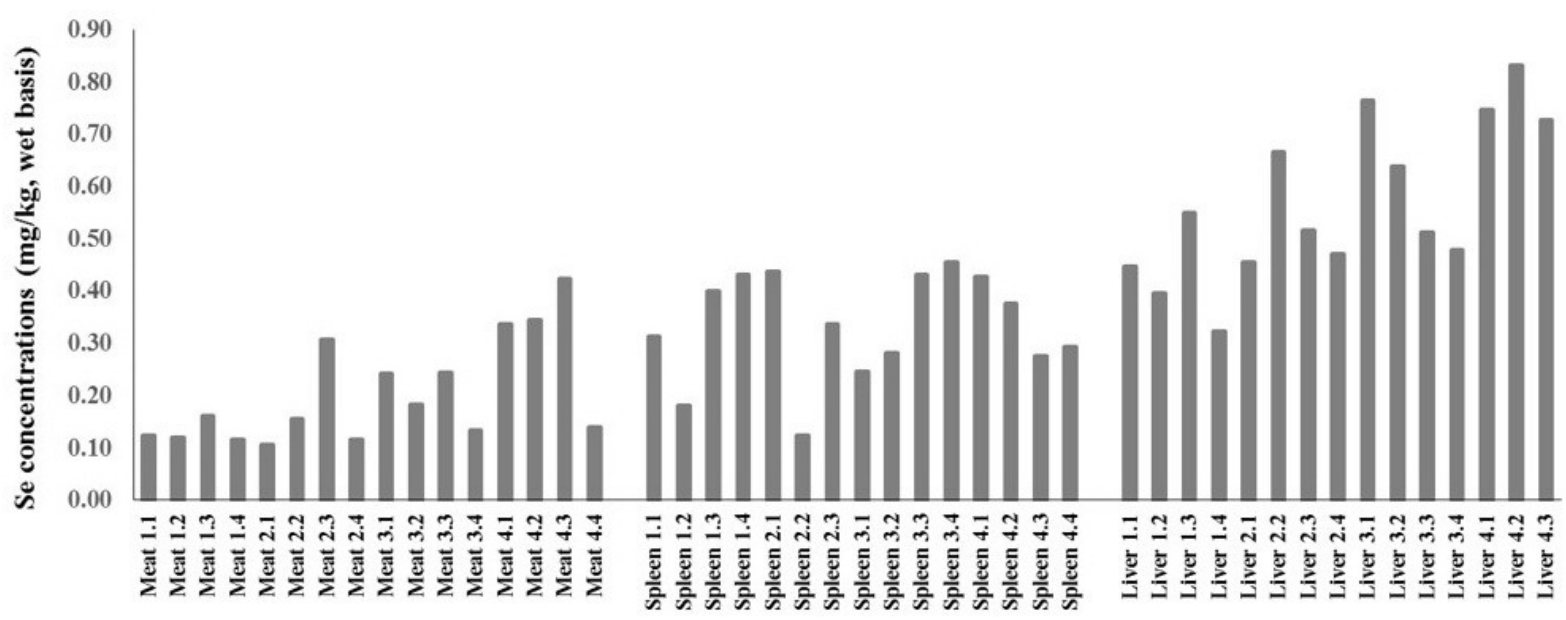

Figure 2. Selenium Concentrations in Meat, Spleen and Liver

response to the selenium supplementation is quite different. The high responders to Se were muscle tissue and liver (Ekholm et al., 1991; JuszczukKubiak et al., 2016; Baltić et al., 2015). In general, in this study the selenium supplementation has increased the selenium in meat and liver. In meat and liver, this diet increased the selenium by a factor of 1.2-2.4. No significant differences for selenium in spleen. While for iron and zinc concentrations, there were no significant differences between control and other groups in meat, spleen and liver. Correlation between concentrations of $\mathrm{Se}, \mathrm{Fe}$ and $\mathrm{Zn}$ in the meat, spleen and liver were resumed in Table 4. There was no significant correlation for $\mathrm{Fe}$ concentrations in meat, and those in spleen and liver, as well as $\mathrm{Zn}$ concentrations. The positive relationship between meat and liver was found for selenium concentrations. This is in line with the selenium supplementation impact in meat and liver.

\section{Selenium}

In this study, the selenium concentrations in meat, spleen and liver from all treatments of groups were varied from 0.11 to $0.83 \mathrm{mg} / \mathrm{kg}$ wet weight, which exceeds the normal range ( 0.070 to $0.150 \mathrm{mg} / \mathrm{kg}$ ) (Blanco-Penedo et al., 2010). Compared to the selenium in fresh meat from US reported by Gerber et al., the selenium in meat previously reported by Setyowati, 2010 were similar with US beef $(0.30$ and $0.44 \mathrm{mg} / \mathrm{kg})$ (Gerber et al., 2009). These results due to that the Brahman cross steers in this study raised on a diet with organic selenium yeast (Setyowati, 2010).
The mean of Se concentrations (Table 2) indicates that $\mathrm{Se}$ as a feed supplement has increased the selenium concentrations. A similar study in comparison to other beef meat from Australia, Denmark, UK and US $(0.10,0.065,0.070$ and $0.308 \mathrm{mg} / \mathrm{kg}$, respectively) showed that the US meat is much more concentrated in Se than meat from Europe (Williamson et al., 2005; Cabrera et al., 2010). In the US, before slaughter the beef cattle are transferred in feedlots, and fed them by selenium supplemented diet feeding (Keck and Finley, 2006). This fact may explain why selenium content of meat from US shows higher than other evaluated meat. In this study, the selenium content in meat, spleen and liver has statistically difference, with the highest concentration is on liver followed subsequently in the spleen and meat, which in agreement with other studies (Ekholm et al., 1991).

\section{Iron}

Among the samples, iron concentrations were found highest in the spleen. The concentration of iron follows the order of spleen $>$ liver $>$ meat. The average concentration of iron in meat, liver and spleen were $11.85 \pm 3.23 \mathrm{mg} / \mathrm{kg}$, $38.94 \pm 13.62 \mathrm{mg} / \mathrm{kg}$ and $139 \pm 76 \mathrm{mg} / \mathrm{kg}$ wet weight, respectively. This is similar with the results from Valenzuela et al., and they showed that the highest level of total iron is in the spleen, because the principal functions of spleen are hemolysis and erythorpoiesis during pregnancy (Valenzuela et al., 2009). The mean and standard deviation of total iron in meat, liver and spleen in their study were $14 \pm 3 \mathrm{mg} / \mathrm{kg}, 60 \pm 1 \mathrm{mg} / \mathrm{kg}$ and 
Table 2. Analysis Results of Fe, $\mathrm{Zn}$ and Se in Meat, Spleen and Liver (mg/kg, wet basis)

\begin{tabular}{|c|c|c|c|c|c|c|c|}
\hline \multirow{2}{*}{$\begin{array}{l}\text { Essential } \\
\text { Trace } \\
\text { Elements }\end{array}$} & \multirow{2}{*}{$\begin{array}{l}\text { Supplementation } \\
\text { Selenium } 0.3 \\
\text { ppm/day }\end{array}$} & \multicolumn{2}{|c|}{ Meat $(n=16)$} & \multicolumn{2}{|c|}{ Spleen $(n=15)$} & \multicolumn{2}{|c|}{ Liver ( $\mathrm{n}=15)$} \\
\hline & & Mean & Range & Mean & Range & Mean & Range \\
\hline \multirow{4}{*}{$\mathrm{Se}$} & Group I & $0.13^{*}$ & $0.12-0.16$ & 0.33 & $0.18-0.43$ & 0.43 & $0.32-0.55$ \\
\hline & Group II & $0.17^{*}$ & $0.11-0.31$ & 0.30 & $0.12-0.44$ & 0.53 & $0.45-0.67$ \\
\hline & Group III & $0.20^{*}$ & $0.14-0.42$ & 0.35 & $0.25-0.46$ & 0.60 & $0.48-0.76$ \\
\hline & Group IV & $0.31^{*}$ & $0.18-0.43$ & 0.34 & $0.28-0.43$ & 0.70 & $0.73-0.83$ \\
\hline \multirow{4}{*}{$\mathrm{Fe}$} & Group I & 8.8 & $7.29-11.6$ & 168.1 & $45-357$ & 41.9 & $20.8-73.2$ \\
\hline & Group II & 12.6 & 8.88-18.2 & 100.0 & 45- 167 & 34.9 & $27.0-46.9$ \\
\hline & Group III & 11.3 & $10.3-13.3$ & 131.5 & 73- 172 & 40.3 & $30.3-49.1$ \\
\hline & Group IV & 14.6 & $12.9-18.4$ & 146.5 & $108-214$ & 36.5 & $31.7-47.7$ \\
\hline \multirow{4}{*}{$\mathrm{Zn}$} & Group I & 20.3 & $16.2-28.7$ & 20.8 & $23.9-35.7$ & 23.1 & $12.8-29.0$ \\
\hline & Group II & 32.5 & $22.3-56.1$ & 19.6 & $10.5-26.7$ & 26.9 & 22.9-31.9 \\
\hline & Group III & 27.8 & $21.5-35.4$ & 20.5 & $12.8-31.9$ & 25.1 & $19.2-33.3$ \\
\hline & Group IV & 31.1 & $23.9-35.7$ & 26.3 & $19.2-31.6$ & 24.5 & $22.6-29.7$ \\
\hline
\end{tabular}

*Values reported by Setyowati (2010); Group I (control); Group II (25 days); Group III (50 days); Group IV (75 days)

Table 3. Statistical of Duncan Test for Selenium Concentrations in Meat and Liver with Different Treatment of Feedings

\begin{tabular}{lccccc}
\hline \multirow{2}{*}{ Treatment } & \multicolumn{2}{c}{ Meat* } & & \multicolumn{2}{c}{ Liver } \\
\cline { 2 - 3 } \cline { 5 - 6 } Group I & Se $(\mathrm{mg} / \mathrm{kg})$ & Significance & & Se $(\mathrm{mg} / \mathrm{kg})$ & Significance \\
Group II & 0.13 & $\mathrm{a}$ & & 0.43 & $\mathrm{a}$ \\
Group III & 0.17 & $\mathrm{a}$ & & 0.53 & $\mathrm{~b}$ \\
Group IV & 0.20 & $\mathrm{ab}$ & & 0.60 & $\mathrm{~b}$ \\
\hline
\end{tabular}

Values with same letters are not significantly different at a $\mathrm{p}$ value $<0.05 ; \quad{ }^{*}$ values reported by Setyowati (2010).

$312 \pm 4 \mathrm{mg} / \mathrm{kg}$, respectively (Valenzuela et al., 2009). Comparison with other study by Pilarczyk showed the iron in meat ranging between 13.3 to $15.7 \mathrm{mg} / \mathrm{kg}$, quite higher than in this study (Pilarczyk, 2014). Where as in the study of Gerber et al., the iron concentrations in sirloin and rib eye from local supermarket and butcheries in Swiss and US varied from 16 to $25 \mathrm{mg} / \mathrm{kg}$ wet weight (Gerber et al., 2009). Simiar to our results,
Cabrera compared the iron content in fresh meat reported by Lombardi-Boccia et al. (18.0-23.7 $\mathrm{mg} / \mathrm{kg}$ ), Kotula and Lusby $(20.8-38.8 \mathrm{mg} / \mathrm{kg}$ ), Purchas et al. (New Zealand beef $19.1 \mathrm{mg} / \mathrm{kg}$ ) and Williamson et al (fresh meat from Australia, Denmark, UK and US shows levels ranged from 16 to $24 \mathrm{mg} / \mathrm{kg}$ wet weight) (Cabrera et al., 2010; Kotula and Lusby, 1982; Lombardi-Boccia et al., 2005; Purchas et al., 2014; Williamson et al., 
Table 4. Correlations between Iron, Zinc and Selenium Concentrations in Meat, Spleen and Liver

\begin{tabular}{cccc}
\hline Elements & $\begin{array}{c}\text { Meat vs } \\
\text { Spleen }\end{array}$ & $\begin{array}{c}\text { Meat vs } \\
\text { Liver }\end{array}$ & $\begin{array}{c}\text { Spleen } \\
\text { vs Liver }\end{array}$ \\
\hline $\mathrm{Se}$ & -0.042 & 0.744 & -0.248 \\
$\mathrm{Fe}$ & -0.142 & 0.145 & 0.335 \\
$\mathrm{Zn}$ & 0.306 & 0.145 & -0.181 \\
\hline
\end{tabular}

2005). It showed that iron concentrations in this study has a similar range with other studies in other countries.

\section{Zinc}

Zinc concentration has the average in a similar range from 21.70 to $25.27 \mathrm{mg} / \mathrm{kg}$ in meat, spleen and liver, with CVs $(20 \%$ to $35 \%)$. The measured values of zinc in this study are lower than the wet weight values reported by Williamson for Denmark, UK, Australia and US beef (40 to $47 \mathrm{mg} / \mathrm{kg}$ ). Gerber for Swiss and US beef $(37-51 \mathrm{mg} / \mathrm{kg})$, Kotula and Lusby (29.5 to $55.1 \mathrm{mg} / \mathrm{kg}$ ) and Puls (20-70 mg/kg) (Gerber et al., 2009; Williamson et al., 2005; Kotula and Lusby, 1982; Lopez Alonso et al., 2000). Puls explained that in the case of $\mathrm{Zn}$ levels of 20-30 and $70 \mathrm{mg} / \mathrm{kg}$ wet weight, were indicated from bright and dark fibre muscles respectively (Lopez Alonso et al., 2000). The zinc content varied according to color and concentrations of myoglobin, and that dark muscles have greater zinc concentrations than bright ones (Gerber et al., 2009). Compared to zinc concentration in meat from Uganda $(6-20 \mathrm{mg} / \mathrm{kg})$, our results show that zinc in meat has a relatively higher content (Tidemann-Andersen et al., 2011). The calculated CVs in this study were in agreement with Gerber, which the low CVs for zinc could be that zinc is mainly genetically determined and only a small part is affected by the feeding (Gerber et al., 2009). In cattle, homeostatic mechanism regulates the $\mathrm{Zn}$ tissue concentrations, and once optimal physiological concentrations are reached (30 $\mathrm{mg} / \mathrm{kg} \mathrm{DM}$ ), supplementation of $\mathrm{Zn}$ shows that there is no effect on $\mathrm{Zn}$ muscles levels (Gerber et al., 2009). Contribution of Meat, Spleen and Liver to
Recommended Daily Allowance (RDA)

The contribution of 100 grams of fresh meat, spleen and liver in studied essential trace elements, were calculated for the RDA for adult male (19-49 years), adults female (19-49 years) and children (4-6 years) as regulated by the Ministry of Health of Indonesia (Ministry of Health Republic Indonesia, 2013). The comparison of meat, spleen and liver contribution to the nutritional requirement of adult male, adult female and children are shown in Figure 3.

For selenium, meat, spleen and liver could fulfill the required RDA in children. For adult male and female, spleen and liver cover more than $100 \%$ of the RDA in Se. The meat studied in this study cover $67 \%$ of the RDA for adults. However, the high content of selenium due to selenium supplementation feeding, makes the meat cuts is potential source for selenium in human nutrition. For iron, only spleen which content high iron could meet the RDA for adult male and children, and about 53\% the RDA for adult female. Other cuts, meat and liver only cover RDA for adult male and children about 9-29\% and 13-41\%, respectively. For zinc, the meat, spleen and liver supply to RDA for adult male from $17 \%$ to $21 \%$, for adult female from $22 \%$ to $28 \%$, and for children from $43 \%$ to $56 \%$. The contribution of the meat, spleen and liver to RDA have been calculated based on 100g-piece wet weight. However, usually the meat is consumed after through the cooking process, therefore there could be slightly different calculated RDA. Even though, other study showed that the cooking caused a weight loss of meat around $40 \%$ due to the significance of water loss, and the minerals content were not essentially decreased (Purchas et al., 2014; Lombardi-Boccia et al., 2005). Besides that, the contributions to RDA were calculated based on $100 \mathrm{~g}$-piece of meat. Considering the low consumption rate of meat by Indonesian people (1.9 kg per capita, which equal to $5 \mathrm{~g} /$ day) (OECD/FAO, 2017), it will decrease the contributions of meat, spleen and liver to the RDA for $\mathrm{Se}, \mathrm{Fe}$ and $\mathrm{Zn}$ about 20 times lower. However, still that meat and other cuts such as spleen and liver is potential source for essential trace elements and with adequate amount of the consumption, it could cover the RDA for these elements. The results obtained in this study would be substantial to update the food composition tables with actual data for assessment and calculation of RDA for the daily dietary intake level. It is important to provide the data as a range than a single data, which give the variation of nutrient value and will make a better calculation 

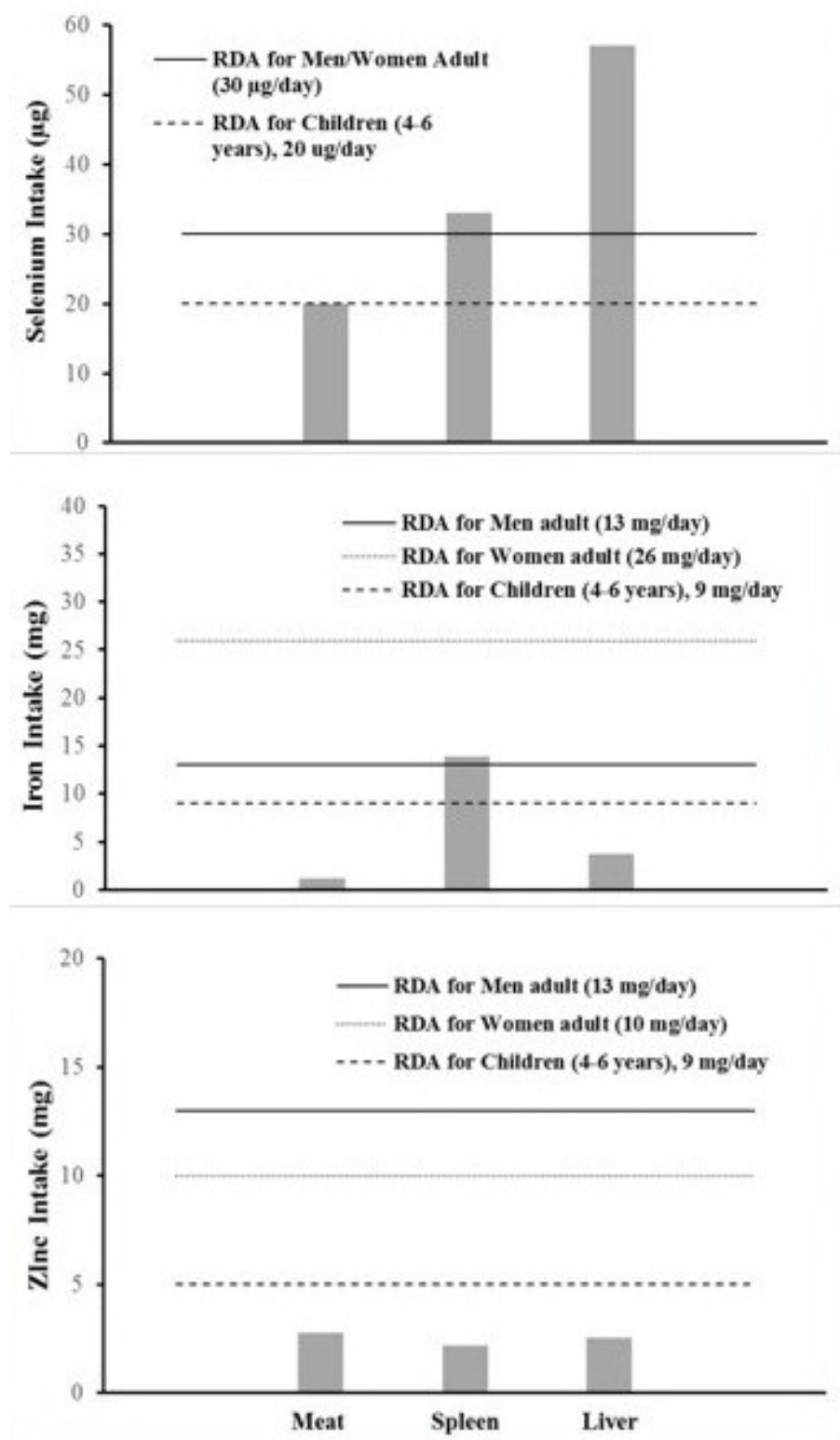

Figure 3. The Selenium, Uron and Zinc Intake per Day from the Contribution of $100 \mathrm{~g}$ of Meat, Spleen and Liver for Adult Male (19-49 Years), Adult Female (19-49 Years), and Children (4-6 Years).

of daily intakes and make it more reliable.

\section{CONCLUSION}

Organic selenium supplementation of 0.3 ppm to the steers showed that it has significant impact on increasing of selenium content in meat and liver after 75 days feeding, while has no impact on other trace elements Fe and $\mathrm{Zn}$. The concentrations of Se was found highest in liver followed by spleen and meat, while $\mathrm{Fe}$ was highest in spleen, and $\mathrm{Zn}$ was found to be in similar range for meat, spleen and liver. Due to the selenium supplementation feeding, evaluated meat, spleen and liver in this study contributes significantly to the RDA of selenium for children and adults. Further study on comparison of the essential trace elemental composition in the meat and meat products after cooking should be carried out to determine the loss of minerals during the process.

\section{ACKNOWLEDGMENTS}

Special gratitude to Padjajaran University for the cooperation for this research, National 
Nuclear Energy Agency (BATAN), researchers from multipurpose research reactor G.A Siwabessy Serpong for assistance in sample irradiation and Radiometry Analytical Technique group for their valuable contribution in preparation and analysis of samples.

\section{REFERENCES}

Abbaspour, N., R. Hurrell and R. Kelishadi. 2014. Review on iron and its importance for human health. J. Res. Med. Sci. 19(2):164174.

Atmodjo, D. P. D., S. Kurniawati, D. D. Lestiani, and N. Adventini. 2017. INAA Application for trace element determination in biological reference material. J. Phys. Conf. Ser. Vol.860, Conf. 1.

Bailey, R. L., K. P. West and R. E. Black. 2015. The epidemiology of global micronutrient deficiencies. Ann. Nutr. Metab. 66(suppl 2): 22-33

Baltić, M., M. Dokmanović Starčevic, M. Bašić, A. Zenunović, J. Ivanović, R. Marković, J. Janjić, and H. Mahmutović. 2015. Effects of selenium yeast level in diet on carcass and meat quality, tissue selenium distribution and glutathione peroxidase activity in ducks. Anim. Feed Sci. Technol. 210:225233

Blanco-Penedo, I., M. López-Alonso, M. Miranda, J. Hernández, F. Prieto and R. F. Shore. 2010. Non-Essential and essential trace element concentrations in meat from cattle reared under organic, intensive or conventional production systems. Food Addit. Contam. - Part A Chem. Anal. Control. Expo. Risk Assess. 27(1):36-42.

Cabrera, M. C., A. Ramos, A. Saadoun and G. Brito. 2010. Selenium, copper, zinc, iron and manganese content of seven meat cuts from hereford and Braford steers fed pasture in Uruguay. Meat Sci. 84(3):518-528.

Czerwonka, M., and A. Szterk. 2015. The Effect of meat cuts and thermal processing on selected mineral concentration in beef from Holstein-Friesian bulls. Meat Sci. 105:7580.

Diana, A., J. J. Haszard, D. M. Purnamasari, I. Nurulazmi, D. E. Luftimas, S. Rahmania, G. I. Nugraha, J. Erhardt, R. S. Gibson and L. Houghton. 2017. Iron, zinc, vitamin A and selenium status in a cohort of Indonesian infants after adjusting for inflammation using several different approaches. Br. J. Nutr. 118 (10): 830-839.

Ekholm, P., P. Varo, P. Aspila, P. Koivistoinen, and L. Syrjälä-Qvist. 1991. Transport of feed selenium to different tissues of bulls. Br. J. Nutr. 66: 49-55.

Elmadfa, I. and A. L. Meyer. 2008. Body composition, changing physiological functions and nutrient requirements of the elderly. Ann. Nutr. Metab. 52 (Suppl. 1):2-5.

Fahmida, U., O. Santika, R. Kolopaking and E. Ferguson. 2014. Complementary feeding recommendations based on locally available foods in Indonesia. Food Nutr. Bull. 35(4): S174-S179.

Gerber, N., R. Brogioli, B. Hattendorf, M. R. L. Scheeder, C. Wenk, and D. Günther. 2009. Variability of Selected Trace Elements of Different Meat Cuts Determined by ICP-MS and DRC-ICPMS. Animal 3(1):166-172.

Hintze, K. J., G. P. Lardy, M. J. Marchello and J. W. Finley. 2002. Selenium accumulation in beef: Effect of dietary selenium and geographical area of animal origin. J. Agric. Food Chem. 50(14): 3938-3942.

IAEA International Atomic Energy Agency. 1992. Sampling and Analytical Methodologies for Instrumental Neutron Activation Analysis of Airborne Paniculate Matter, No. 4.

Juszczuk-Kubiak, E., K. Bujko, M. Cymer, K. Wicińska, M. Gabryszuk and M. Pierzchała. 2016. Effect of inorganic dietary selenium supplementation on selenoprotein and lipid metabolism gene expression patterns in liver and loin muscle of growing lambs. Biol. Trace Elem. Res. 172(2):336-345.

Keck, A. S. and J. W. Finley. 2006. Database values do not reflect selenium contents of grain, cereals, and other foods grown or purchased in the upper midwest of the United States. Nutr. Res. 26(1):17-22.

King, J. C., K. H. Brown, R. S. Gibson, N.F. Krebs, N. M. Lowe, J. H. Siekmann and D. J. Raiten. 2016. Biomarkers of nutrition for development (BOND)-Zinc Review. J. Nutr. 146(9): 858S-885S

Kotula, A. W. and W. R. Lusby. 1982. Mineral composition of muscles of 1-to 6-year-old steers. J. Anim. Sci. 54(3):544-548.

Lynch, S., C. M. Pfeiffer, M. K. Georgieff, G. Brittenham, S. F. Tait, R. F. Hurrel, H. J. McArdle and D. J. Raiten. 2016. Biomarkers of nutrition for development (BOND)-Iron Review. J. Nutr. 146(9): 


\section{S-1067S}

Lombardi-Boccia, G., S. Lanzi and A. Aguzzi. 2005. Aspects of meat quality: Trace elements and B vitamins in raw and cooked meats. J. Food Compos. Anal. 18(1):39-46.

Lopez Alonso, M., J. L. Benedito, M. Miranda, C. Castillo, J. Hernandez and R. F. Shore. 2000. Toxic and trace elements in liver, kidney and meat from cattle slaughtered in Galicia (NW Spain). Food Addit. Contam. 17(6): 447-457.

Ministry of Health Republic Indonesia. 2013. Peraturan Kementrian Kesehatan no.75.

Ministry of Health Republic Indonesia. 2016. Pemantauan Status Gizi Indonesia 2016 (Indonesian). http://www.kesmas.kemkes. go.id/assets/upload/dir_519d41d8cd98f00/fi les/Buku-Saku-Hasil-PSG-2016_842.pdf.

Mutakin, I. F. Rivai, A. Setiawan, R. A bdulah, K. Kobayashi, C. Yamazaki, S. Kameo, M. Nakazawa and H. Koyama. 2016. A Study of the association between selenium and cardiovascular disease in Lampung, Indonesia. Southeast Asian J. Trop. Med. Public Health 47 (2): 299-308

Moon, J. H., S. H. Kim, Y. S. Chung and O. Lee. 2015. Application of instrumental neutron activation analysis to assess dietary intake of selenium in Korean adults from meat and eggs. J. Radioanal. Nucl. Chem. 303(2): 1561-1564.

Natalia, A., D. D. Lestiani, Y. N. . Niken and M. Santoso. 2011. Analysis of micronutrients in meat, spleen and liver of cows using NAA. Proceedings, Sci. Technol. Nucl. P.185-191.

Natalia, A., S. Muhayatun, K. Syukria and E. Setyowati. 2010. Determination of Micromineral $\mathrm{Fe}$ on Cow Meat and Liver. Proceedings, Natl. Semin. Neutron Act. Anal. P. 242-247.

OECD/FAO. 2017. OECD-FAO Agricultural Outlook 2017-2026. doi:http://dx.doi.org/ 10.1787/agr_outlook-2017-en.

Pereira, V., M. López-Alonso, M. Miranda, J. L. Benedito and M. García-Vaquero. 2017. Relationship between the essential and toxic element concentrations and the proximate composition of different commercial and internal cuts of young beef. Eur. Food Res. Technol. 243(10):1869-1873

Pilarczyk, R. 2014. Concentrations of toxic and nutritional essential elements in meat from different beef breeds reared under intensive production systems. Biol. Trace Elem. Res. 158(1):36-44.

Purchas, R. W., B. H. P. Wilkinson, F. Carruthers and F. Jackson. 2014. A Comparison of the nutrient content of uncooked and cooked lean from New Zealand beef and lamb. J. Food Compos. Anal. 35(2):75-82.

Saini, R. K., S. H. Nile and Y.-S. Keum. 2016. Food Science and Technology for Management of Iron Deficiency in Humans: A Review. Trends in Food Science \& Technology. Vol. 53. Elsevier Ltd.

Seboussi, R., B. Faye, G. Alhadrami, M. Askar, W. Ibrahim, B. Mahjoub, K. Hassan, T. Moustafa and A. Elkhouly. 2010. Selenium distribution in camel blood and organs after different level of dietary selenium supplementation. Biol. Trace Elem. Res. 133(1):34-50.

Setyowati, E. 2010. The Effect of Organic Selenium Supplemented Duration on the Production Performance and Meat Quality of Brahman Cross. Disertation, Faculty of Animal Husbandry, Padjajaran University.

Syahfitri, W. Y. N., S. Kurniawati, N. Adventini, E. Damastuti and D. D. Lestiani. 2017. Macro elemental analysis of food samples by nuclear analytical technique. J. Phys. Conf. Ser. Vol. 860. Conf 1.

Tidemann-Andersen, I., H. Acham, A. Maage and M. K. Malde. 2011. Iron and zinc content of selected foods in the diet of schoolchildren in Kumi District, East of Uganda: A CrossSectional Study. Nutr. J. 10 (1):81.

Valenzuela, C., D. López De Romaña, M. Olivares, M. S. Morales, and F. Pizarro. 2009. Total iron and heme iron content and their distribution in beef meat and viscera. Biol. Trace Elem. Res. 132(1-3):103-111.

Vignola, G., L. Lambertini, G. Mazzone, M. Giammarco, M. Tassinari, G. Martelli and G. Bertin. 2009. Effects of selenium source and level of supplementation on the performance and meat quality of lambs. Meat Sci. 81(4):678-685.

Williamson, C. S., R. K. Foster, S. A. Stanner and J. L. Buttriss. 2005. Red Meat in the diet. Nutr. Bull. 30(4):323-355. 